\title{
COINTEGRATION INDEKS HARGA SAHAM GABUNGAN DAN JAKARTA ISLAMIC INDEX PERIODE 2015-2019
}

\author{
Ahmad Hilmy \\ Universitas Negeri Surabaya \\ hilmy007@gmail.com \\ Yuyun Isbanah \\ Universitas Negeri Surabaya \\ yuyunisbanah@unesa.ac.id
}

\begin{abstract}
Examines co-movement between IHSG and JII that represent conventional stock indices and shariah stock indices in the 2015-2019 period was to be the focus on this paper. Co-movement studies have benefits for investors to have diversification opportunities on their portfolio investments asset and their decision making in the future. This study examines how the two different assets characteristic move in long term relationships and short-term relationships. The sample data have gathered from the monthly closing price in five years range. Any method that used in this study using The Augmented Dickey-Fuller Test for stationarity test, Johansen Test for Cointegration, Error Correction Model for a short-run relationship, and Granger causality test for finding any causality between two variables. The data sample using a non-probability sampling technique. This study reveals evidence if two indices variables not co-movement in each other especially not cointegrating and not have any causality between them in the 2015-2019 period. These findings also hav
\end{abstract}

Keywords: cointegration; co-movement; diversification; Granger causality.

\section{PENDAHULUAN}

Perkembangan dalam bidang ekonomi yang sangat pesat memberikan dampak yang positif maupun negatif bagi suatu negara khususnya di Indonesia. Salah satu perkembangan dibidang ekonomi yang memiliki kontribusi secara luas yaitu adalah perkembangan pasar modal. Data acuan yang dapat digunakan investor dalam menganalisis aktivitas ekonomi di bidang pasar modal adalah indeks harga (Tandelilin, 2010:86).

Menurut Fauzan \& Suhendro (2018), peluncuran pasar modal berbasis syariah secara resmi didirikan pada tahun 2003 dengan kesepakatan antara Dewan Syariah Nasional Majelis Ulama Indonesia (DSNMUI) dan Badan Pengawas Pasar Modal (BAPEPAM) yang sekarang berganti nama menjadi Otoritas Jasa Keuangan (OJK) untuk bersama-sama melakukan pengembangan pasar modal yang berbasis syariah.

Jenis instrumen dan mekanisasi transaksi dalam aktivitas perdagangan pasar modal menjadi perbedaan mendasar yang terdapat pada pasar modal syariah dan konvensional (Yaqin, 2010). Perkembangan instrumen berbasis syariah yang tercatat dalam Daftar Efek Syariah (DES) dibagi menjadi beberapa jenis yaitu saham syariah, sukuk, dan reksa dana Syariah (Bursa Efek Indonesia, 2019). Efek syariah yang memiliki persentase market share terbesar dari sisi jumlah efek syariah yaitu dimiliki oleh saham syariah dengan persentase sebesar 47,24 \% (Otoritas Jasa Keuangan, 2019).

Antusiasme masyarakat indonesia terhadap pasar modal syariah di Indonesia semakin meningkat dari tahun ke tahun yang ditunjukkan oleh kenaikan jumlah pangsa pasar dari efek syariah yang didukung oleh peningkatan jumlah investor syariah yang meningkat sebesar $2.323 \%$ menjadi 62.840 investor di bulan Oktober pada tahun 2019 dari 2.705 investor pada tahun 2014 dalam kurun waktu lima tahun terakhir (Kompas, 2019).

Penyebab peningkatan transisi dari sistem keuangan yang berbasis konvensional menuju syariah menurut El Qorchi (2005) ada tiga hal. Pertama, besarnya permintaan akan penerapan layanan 
keuangan berbasis syariah dari komunitas masyarakat Muslim di dunia. Kedua, tingginya permintaan yang sangat signifikan dari negara-negara penghasil minyak di Timur Tengah yang lebih tertarik berinvestasi pada instrumen syariah. Ketiga, berbagai instrumen syariah memiliki tingkat kemampuan untuk bersaing yang tidak hanya dapat meningkatkan antusiasme investor dari kalangan Muslim tetapi juga dari kalangan non-Muslim.

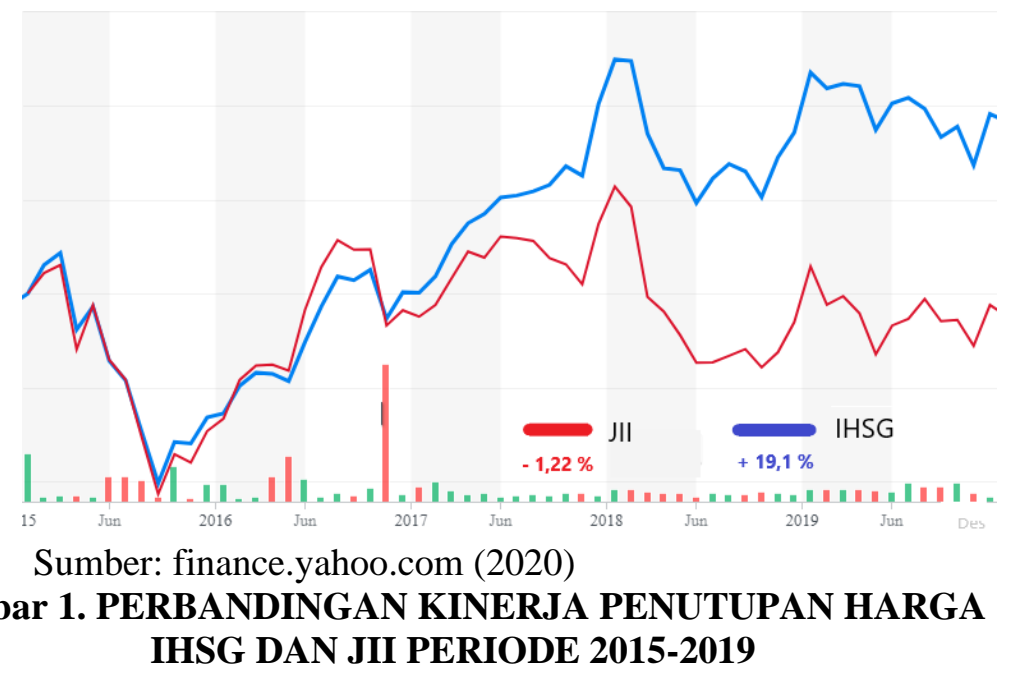

Kinerja Indeks Harga Saham Gabungan berdasarkan penutupan pada periode 2015-2019 mencatat kenaikan positif sebesar 19,1\%, sedangkan kinerja Jakarta Islamic Index berdasarkan penutupan harga mencatat penurunan negatif sebesar $-1,22 \%$. Kenaikan tertinggi pada IHSG maupun JII terjadi pada bulan yang sama yaitu Januari tahun 2018, sedangkan penurunan di titik terendah pada IHSG maupun JII berada di bulan yang sama pada September 2015 .

Pola grafik indeks saham JII dan IHSG secara visual memiliki kecenderungan pola pergerakan yang sama dalam kurun waktu 2015-2019 sehingga dapat dikatakan memiliki kecenderungan untuk mengalami co-movement. Hal ini menimbulkan pertanyaan apakah dua indeks saham tersebut memiliki hubungan keterkaitan antar indeks saham secara empiris sehingga perlu dibuktikan secara empiris pula. Pemilihan Indeks Harga Saham Gabungan yang digunakan sebagai proksi indeks saham konvensional didasari pada adanya kesamaan beberapa emiten di IHSG dengan JII serta dalam IHSG tidak terdapat kriteria khusus untuk semua emiten berada di dalamnya.

Pergerakan pasar modal dalam suatu lingkup negara khususnya lingkup regional memiliki kecenderungan untuk bergerak bersama (co-movement) satu sama lain antar instrumen yang terdapat dalam pasar modal regional sehingga menimbulkan contagion effect yang tinggi (Saiti, 2014). Berbagai pergerakan bersama (co-movement) bisa terjadi karena beberapa hal yaitu adanya integrasi faktor internal maupun eksternal. keuntungan pergerakan bersama dalam instrumen keuangan yaitu dapat meningkatan potensi diversifikasi portofolio (Safwan, 2016). Hal ini juga diungkap dalam studi tentang co-movement yang dilakukan oleh Utami (2018) terkait krisis finansial pada tahun 2008 yang menyebabkan contagion effect yang tinggi pada pasar modal di kawasan ASEAN 5. Studi tentang penelitian co-movement semakin berkembang tidak hanya mempelajari perilaku pasar modal konvensional tetapi juga berkembang pada pasar modal syariah yang memiliki kriteria khusus dalam pemilihan saham nya.

Berbagai penelitian yang mengungkap tentang pola-pola pergerakan bersama sangat banyak dijumpai dalam lingkup lintas antar negara (Jebran, et al., 2017) sehingga terdapat perbedaan mendasar terkait kriteria yang akan diteliti yaitu kriteria saham syariah yang berbeda dengan saham konvensional. Studi mengenai co-movement terkait pasar modal syariah masih belum banyak diteliti (Saiti, 2014). Pentingnya mengetahui pergerakan harga bersama khususnya instrumen yang terdapat pada pasar modal syariah memiliki beberapa keuntungan bagi investor untuk melakukan diversifikasi portofolio 
supaya bisa mendapatkan imbal hasil yang optimal (Safwan, 2016). Selain itu, co-movement yang terjadi pada instrumen di pasar modal syariah bisa digunakan untuk mempelajari bagaimana perilaku harga dari instrumen syariah ketika terjadi krisis finansial pada tahun 2008 yang berdampak pada negara-negara di dunia (Majdoub, et al., 2016).

Salah satu cara untuk mengetahui apakah suatu instrumen yang akan diteliti memiliki co-movement bisa dilakukan dengan mengukur tingkat integrasi yang didapat dari hubungan keseimbangan jangka panjang maupun jangka pendek antar instrumen. Salah satunya bisa dilakukan dengan uji kointegrasi (El Amri \& Hamza, 2017) dengan mempertimbangkan berbagai aspek secara teknis.

Penelitian empiris yang membuktikan apakah terdapat hubungan jangka panjang atau yang disebut kointegrasi pada indeks saham syariah maupun konvensional diungkap dalam beberapa penelitian misalnya penelitian yang dilakukan oleh Majdoub, et al (2016) bahwa terdapat kointegrasi antara indeks saham syariah dan konvensional pada negara Indonesia, Prancis, dan United States sedangkan pada United Kingdom tidak terdapat kointegrasi. Berbeda dengan penelitian yang dilakukan oleh El Amri \& Hamza (2017) bahwa mayoritas indeks saham yang diteliti tidak mengalami kointegrasi. Hal ini menimbulkan berbagai pertanyaan mengenai karakteristik indeks saham syariah maupun konvensional yang mengalami kointegrasi. Terdapat juga penelitian yang mengungkap bagaimana tingkat kointegrasi yang terjadi pada indeks saham syariah maupun konvensional di Indonesia, salah satunya merupakan penelitian yang dilakukan oleh Wibowo (2017) yang menemukan bahwa indeks saham konvensional di Indonesia memiliki hubungan keseimbangan jangka panjang terhadap indeks saham syariah beserta tingkat volatilitasnya.

Penelitian ini bertujuan untuk mengetahui apakah variabel IHSG dan JII memiliki hubungan keseimbangan jangka panjang, hubungan keseimbangan jangka pendek, maupun hubungan kausalitas yang memiliki informasi mengenai pergerakan harga.

\section{KAJIAN PUSTAKA DAN PENGEMBANGAN HIPOTESIS}

\section{Teori Pergerakan Bersama (Co-movement Theory)}

Analisis pergerakan pasar saham Menurut Baur (2003) dinilai penting untuk penerapan diversifikasi portofolio yang efektif dan bisa menjadi titik awal yang memungkinkan untuk menyelidiki fungsi sistem keuangan global. Hal ini sangat penting ketika menilai krisis keuangan khususnya mengenai efek menular. Namun, studi tentang pergerakan pasar bersama juga menarik dalam dua hal. Pertama, tidak ada definisi yang jelas maupun ambigu tentang pergerakan bersama dan tidak ada ukuran unik yang terkait dengannya. Bahkan ejaannya terombang-ambing antara comovement dan co-movement. Kedua, co-movement sulit untuk diperkirakan dalam konteks waktu yang bervariasi jika didasarkan pada koefisien korelasi.

Menurut Baur (2003), koefisien korelasi masih belum cukup untuk mengukur pergerakan bersama dalam konteks co-movement. Selain itu, koefisien korelasi menunjukkan berbagai ketidakakuratan yang membuat definisi dan ukuran baru diperlukan. Tidak adanya definisi unik pergerakan bersama juga sangat kontras dengan formalitas matematika yang biasanya digunakan dalam pemodelan hubungan ekonomi dan keuangan.

Dampak pergerakan dua instrumen atau lebih yang memiliki keterkaitan terhadap instrumen lainnya disebut pergerakan bersama atau co-movement (Baur, 2003). Timbulnya pergerakan bersama sifatnya relatif dan beragam untuk setiap jenis instrumen keuangan. Pergerakan bersama yang terjadi pada suatu negara bisa menimbulkan ketidakstabilan pada suatu kondisi ekonomi contohnya peristiwa krisis finansial (El Amri \& Hamza, 2017).

\section{Indeks Harga Saham Gabungan (IHSG)}

Indeks Harga Saham Gabungan merupakan salah satu indikator pergerakan semua emiten saham yang terdapat di Bursa Efek Indonesia yang berasal dari nilai rata-rata tertimbang aktivitas perdagangan saham seluruh emiten di Bursa Efek Indonesia (Bursa Efek Indonesia, 2019) 


\section{Jakarta Islamic Index}

Jakarta Islamic Index merupakan salah satu indikator pergerakan emiten saham yang memiliki karakteristik syariah yang terdapat di Bursa Efek Indonesia yang berasal dari nilai rata-rata tertimbang aktivitas perdagangan berjumlah 30 emiten saham di Bursa Efek Indonesia (Bursa Efek Indonesia, 2019)

\section{Hubungan Keseimbangan dan Kausalitas}

Penelitian yang mengungkap tentang pergerakan bersama secara global diungkap dalam penelitian Saiti \& Masih (2016) di mana tujuan penelitian ini dilakukan untuk mengetahui pergerakan bersama Shariah China Index, mengetahui hubungan sebab-akibat dengan 3 indeks syariah serta 4 indeks konvensional yaitu FTSE Shariah China Index, Asia Shariah Index, Malaysia EMAS Shariah Index, China Shanghai Stock Exchange (SSE). Sampel yang digunakan dalam penelitian tersebut diambil sejak periode 2007-2011. Hasil penelitian tersebut menunjukkan bahwa Shariah China Index mengalami hubungan keseimbangan jangka panjang dengan semua indeks saham syariah dan indeks saham konvensional yang diteliti. Hal ini memberikan gambaran bahwa Shariah China Index memiliki pergerakan bersama yang diukur dengan menguji kointegrasi nya. Informasi mengenai hubungan jangka pendek dalam penelitian Saiti \& Masih (2016) terjadi sekitar 30-60 hari sampai kembali ke titik ekuilibrium jangka panjangnya.

Berbeda dengan hasil penelitian yang dilakukan oleh Saiti (2014) untuk mengetahui hubungan keseimbangan jangka panjang antara indeks konvensional dan indeks syariah MSCI di beberapa negara yaitu US, China, Jepang, Korea, Taiwan, Hong kong, Malaysia, Indonesia, Turki dan beberapa negara yang pernah menjadi konstituen Saudi MSCI Conventional and Shariah Index. Hasil penelitian menunjukkan beberapa negara ada yang mengalami kointegrasi dan tidak mengalami kointegrasi sehingga investor mendapatkan keuntungan untuk melakukan diversifikasi portofolio pada indeks saham yang tidak mengalami kointegrasi.

Hubungan jangka pendek yang ditemukan dalam penelitian Khan \& Khan (2018) pada indeks saham konvensional Asia pasifik dan Dow Jones Islamic Market Asia Pacific terjadi sekitar 3-5 bulan dan hubungan kausalitas yang terjadi berupa unidirectional. Beberapa penelitian yang menggambarkan indeks saham syariah dan konvensional di Indonesia saling berkointegrasi satu sama lain diungkap oleh sejumlah peneliti yaitu Wibowo (2017), Yusuf, et al (2018), Mardatillah \& Satibi (2018), Muhajir (2008).

Penelitian yang dilakukan oleh Wibowo (2017) yang mengungkap pergerakan bersama antara IHSG, JII dan beberapa variabel makroekonomi yaitu suku bunga dalam periode Maret 2013-Maret 2017. Penelitian ini selain menguji kointegrasi tetapi juga melakukan uji volatilitas dengan metode Markov Switching Regime. Hasil penelitian tersebut mengungkapkan bahwa IHSG mengalami kointegrasi dengan JII dengan menggunakan GARCH. Sama seperti hasil penelitian sebelumnya, penelitian yang dilakukan oleh Yusuf, et al (2018) yang meneliti terkait indeks saham konvensional menggunakan LQ45 dan indeks saham syariah menggunakan JII menunjukkan bahwa kedua indeks tersebut saling berkointegrasi dengan nilai trace statistic > critical value dan memiliki hubungan kausalitas unidirectional ditandai dengan munculnya nilai F-stat > F-tabel, dari JII ke LQ45.

Penelitian yang mengungkap hubungan keseimbangan jangka panjang antara indeks saham konvensional diproksikan dengan IHSG dan indeks saham syariah diproksikan melalui JII menunjukkan dua indeks tersebut saling berkointegrasi yang diteliti oleh Muhajir (2008).

H1: Indeks Harga Saham Gabungan memiliki hubungan keseimbangan jangka panjang terhadap Jakarta Islamic Index.

H2: Indeks Harga Saham Gabungan memiliki hubungan keseimbangan jangka pendek terhadap Jakarta Islamic Index. 
Ahmad Hilmy \& Yuyun Isbanah. Cointegration Indeks Harga Saham Gabungan dan Jakarta Islamic Index Periode 2015-2019

H3 : Indeks Harga Saham Gabungan memiliki hubungan kausalitas terhadap Jakarta Islamic Index.

\section{METODE PENELITIAN}

Penelitian ini dilakukan dengan pendekatan secara kuantitatif dan juga merupakan jenis penelitian kausalitas. Tahap selanjutnya dilakukan perhitungan sesuai prosedur serta dilakukan interpretasi melalui hasil analisis dari objek penelitian yang di observasi. Populasi dalam penelitian ini yaitu closing price dari Indeks Harga Saham Gabungan dan Jakarta Islamic Index periode 2015-2019. Sampling dari penelitian ini menggunakan non-probability sampling dengan teknik sampling jenuh. Sampel diperoleh dari monthly closing price selama 5 tahun setiap bulannya mulai bulan Januari 2015 sampai Desember 2019. Jumlah sampel yang digunakan dalam penelitian ini yaitu berjumlah 120 sampel dengan rincian 60 sampel didapat dari monthly closing price IHSG dan 60 sampel didapat dari monthly closing price JII. Analisis yang digunakan dalam penelitian ini menggunakan analisis runtun waktu yang merupakan pengembangan dari bidang Ekonometrika. Teknis analisis data yang digunakan dalam penelitian ini adalah Uji Kointegrasi untuk mengetahui hubungan keseimbangan jangka panjang, Error Correction Model untuk mengetahui hubungan keseimbangan jangka penjek, dan uji Granger Causality untuk mengukur hubungan kausalitas antar variabel.

\section{HASIL DAN PEMBAHASAN}

\section{Uji Stasioneritas Data}

Stasioneritas suatu data dapat dipenuhi oleh beberapa syarat yaitu nilai $t$-statistic yang diperoleh melalui ADF Test memenuhi syarat yaitu $t$-statistic > Critical Value $(1 \%, 5 \%, 10 \%)$. tabel berikut menyajikan data hasil perhitungan dari $A D F$ Test. Hasil uji akar unit di tingkat level / I(0) menunjukkan bahwa data belum mengalami stasioneritas karena nilai $t$-statistic $<C V(1 \%, 5 \%, 10 \%)$ sehingga data dilakukan uji akar unit kedua kalinya di tingkat diferensi pertama/ I(1). Data kedua yang dihasilkan pada tingkat diferensi pertama/ I(1) menunjukkan data sudah mengalami stasioneritas dimana $t$-statistic > CV $(1 \%, 5 \%, 10 \%)$. Hasil dari uji akar unit ini menunjukkan bahwa dari hasil uji di tingkat level/ I(0) memiliki sifat deterministic trend pada kedua indeks yang diinterpretasikan bahwa data memiliki akar unit (Saiti, 2014).

Tabel 1.

UJI STASIONERITAS

\begin{tabular}{|c|c|c|c|}
\hline Augmented Dickey Fuller Test & Keterangan & Variabel & Probability \\
\hline \multirow[t]{10}{*}{ Hasil Uji Akar Unit Tingkat Level / I(0) } & \multirow[t]{2}{*}{$t$-Statistic } & IHSG & $-0,863073$ \\
\hline & & JII & $-2,072710$ \\
\hline & \multirow[t]{2}{*}{ CV $1 \%$} & IHSG & $-3,546099$ \\
\hline & & JII & $-3,546099$ \\
\hline & \multirow[t]{2}{*}{ CV $5 \%$} & IHSG & $-2,911730$ \\
\hline & & JII & $-2,911730$ \\
\hline & \multirow[t]{2}{*}{ CV $10 \%$} & IHSG & $-2,593551$ \\
\hline & & JII & $-2,593551$ \\
\hline & \multirow[t]{2}{*}{ Probability } & IHSG & 0,7931 \\
\hline & & JII & 0,2562 \\
\hline \multirow[t]{10}{*}{ Hasil Uji Akar Unit Tingkat Level / I(1) } & \multirow[t]{2}{*}{$t$-Statistic } & D(IHSG) & $-7,015237$ \\
\hline & & $\mathrm{D}(\mathrm{JII})$ & $-7,174091$ \\
\hline & \multirow[t]{2}{*}{ CV $1 \%$} & D(IHSG) & $-3,548208$ \\
\hline & & $\mathrm{D}(\mathrm{JII})$ & $-3,548208$ \\
\hline & \multirow[t]{2}{*}{ CV $5 \%$} & D(IHSG) & $-2,912631$ \\
\hline & & $\mathrm{D}(\mathrm{JII})$ & $-2,912631$ \\
\hline & \multirow[t]{2}{*}{ CV $10 \%$} & D(IHSG) & $-2,594027$ \\
\hline & & $\mathrm{D}(\mathrm{JII})$ & $-2,594027$ \\
\hline & \multirow[t]{2}{*}{ Probability } & D(IHSG) & 0.0000 \\
\hline & & $\mathrm{D}(\mathrm{JII})$ & 0.0000 \\
\hline
\end{tabular}

Sumber: Output Eviews 10 (data diolah) 


\section{Uji Kointegrasi}

Tabel 2.

\section{UJI KOINTEGRASI}

\begin{tabular}{cccc}
\hline Variabel & Trace Statistic & Critical Value 5\% & Probability \\
\hline JII, IHSG & 0,000962 & 3,841466 & 0,8132 \\
\{IHSG, JII & 0,055822 & 3,841466 & 0,8132 \\
\hline
\end{tabular}

Sumber: Output Eviews 10 (data diolah)

Uji kointegrasi dapat dikatakan sangat penting dalam menguji apakah hubungan variabel secara teori saling berhubungan atau tidak (Winarno, 2017:70). Jika kedua variabel mengalami kointegrasi artinya variabel mengalami co-movement dalam jangka panjang dalam hubungan ekuilibriumnya. Penelitian ini menggunakan uji kointegrasi dengan "Johansen Test" karena metode ini menghasilkan hasil yang lebih superior dibanding metode lain (Saiti \& Masih, 2016). Sebelum melakukan prosedur Johansen Test, ada beberapa persyaratan yang harus dilakukan yaitu dibutuhkan "lag optimal" untuk vector auto regression (VAR). Pemilihan lag optimal didasarkan pada pemilihan AIC (Saiti \& Masih, 2016). berdasarkan hasil penentuan lag optimal yang ditemukan AIC nya terkecil adalah pada lag 1 karena memiliki nilai AIC yang tekecil diantara lag lain sebesar 20,38114.

Penentuan estimasi untuk hubungan keseimbangan jangka panjang dengan menggunak Johansen Test menunjukkan bahwa kedua variabel tidak mengalami kointegrasi. Variabel tidak mengalami kointegrasi pada semua jenis data trend. Hasil uji kointegrasi dengan asumsi linear deterministic trend diperoleh melalui tahap uji stasioneritas yang telah dilakukan pada tahap proses awal.

Variabel tidak mengalami kointegrasi untuk variabel JII terhadap IHSG yang ditunjukkan dengan nilai Trace Statistic sebesar 0,000962 < Critical Value sebesar 3,841466 dengan probabilitas 0,8132 dan nilai Max-eigen statistic sebesar 0,055822 < Critical Value sebesar 3,841466 dengan probabilitas 0,8132 sedangkan untuk hasil uji kointegrasi IHSG terhadap JII juga menghasilkan data yang menunjukkan bahwa tidak adanya kointegrasi dengan nilai Trace Statistic sebesar 0,055822 < Critical Value sebesar 3,841466 dengan probabilitas 0,8132 dan nilai Max-eigen statistic sebesar 0,055822 < Critical Value sebesar 3,841466 dengan probabilitas 0,8132. Hasil ini menunjukkan bahwa kedua variabel tidak mengalami kointegrasi sehingga menolak hipotesis pertama yaitu H1. Maka selanjutnya untuk pengujian hipotesis yang kedua yaitu $\mathrm{H} 2$ dimana untuk menguji hubungan jangka pendek tidak dapat dilakukan karena tidak terjadi kointegrasi.

\section{Uji Kausalitas Granger}

Tabel 3. UJI KAUSALITAS GRANGER

\begin{tabular}{ccc}
\hline Null Hypothesis & F-Statistic & Probability \\
\hline JII does not Granger Cause IHSG & 0,48385 & 0,4896 \\
IHSG does not Granger Cause JII & 0,00237 & 0,9614 \\
\hline
\end{tabular}

Sumber: Output Eviews 10

Analisis kausalitas menggunakan metode Engle-Granger digunakan untuk menguji signifikansi serta arah dari hubungan kausalitas diantara variabel yang diuji (Rosadi, 2012:200). Hasil uji kausalitas ini menggunakan nilai F-statistik serta menggunakan taraf signifikansi 5\% untuk memenuhi syarat terpenuhi nya suatu variabel mengalami kausalitas. Hasil uji kausalitas dalam penelitian menunjukkan bahwa variabel IHSG tidak mengalami memiliki hubungan sebab akibat terhadap variabel JII dan maupun sebaliknya. Nilai tabel F-statistik pada taraf signifikansi 5\% sebesar 4,01 sehingga nilai Fstatistik kedua variabel $<\mathrm{F}$ statistik tabel dan nilai probabilitas $>0,05$ sehingga kedua variabel disimpulkan tidak memiliki hubungan kausalitas. Uji kausalitas ini menunjukkan adanya penolakan terhadap H3 sehingga IHSG tidak memiliki hubungan kausalitas terhadap JII. 
Ahmad Hilmy \& Yuyun Isbanah. Cointegration Indeks Harga Saham Gabungan dan Jakarta Islamic Index Periode 2015-2019

\section{Hubungan Keseimbangan Jangka Panjang IHSG dengan JII}

Hasil proses running tahapan pengolahan data yang berasal dari monthly closing price menunjukkan temuan yaitu hasil uji kointegrasi dengan menggunakan metode Johansen Test mengungkap bahwa variabel IHSG dan JII pada periode 2015-2019 antara satu sama lain tidak mengalami kointegrasi.

Temuan ini memiliki hasil yang berbeda dari beberapa penelitian yang diungkap oleh Saiti \& Masih (2016), Wibowo (2017), Yusuf, et al (2018), Mardatillah \& Satibi (2018), dan Muhajir (2008) bahwa indeks saham konvensional mengalami kointegrasi dengan indeks saham syariah. Namun ada beberapa kesamaan dalam penelitian dalam hasil penelitian yang diteliti oleh Saiti (2014) dan Majdoub, et al (2016) ditemukan adanya beberapa indeks saham yang tidak mengalami kointegrasi.

Temuan ini juga bisa disebabkan oleh berbagai macam kemungkinan penyebab seperti dalam studi yang dilakukan oleh Majdoub, et al (2016) dan Wibowo (2017) bahwa kointegrasi suatu indeks saham bisa disebabkan oleh karakter industri keuangan syariah yaitu lebih cenderung dipengaruhi oleh tingkat transmisi volatilitas interest rate. Namun apabila pemberlakuan screening dengan perspektif syariah dengan minimalisasi tingkat interest rate sudah dilakukan secara ketat maka diduga model ekonomi yang didominasi dari foreign investment menjadi penyebab signifikansi terhadap tingkat transmisi volatilitas interest rate (Wibowo, 2017). Lebih jauh, perlu penelitian lebih lanjut untuk menganalisis faktor-faktor penyebabnya.

Secara teoritis, temuan ini memberi implikasi bahwa IHSG dan JII tidak memiliki keterkaitan satu sama lain atau tidak memiliki "co-movement". Namun secara praktis, tidak adanya kointegrasi memiliki implikasi bahwa kesempatan diversifikasi pada aset investasi yang dikelola sehingga investor bisa memiliki kualitas pertimbangan dalam hal pengambilan keputusan investasi bisa dicapai serta bisa menjadi alat bantu bagi pengambil kebijakan di bidang pasar modal di Indonesia.

\section{Hubungan Keseimbangan Jangka Pendek IHSG dengan JII}

Temuan tidak adanya hubungan kesimbangan jangka pendek melalui error correction model disebabkan kedua variabel tidak mengalami hubungan kesimbangan jangka panjangnya sehingga variabel tidak mengalami hubungan ekuilibrium secara jangka panjang maupun jangka pendek dalam periode 2015-2019.

Temuan ini berbeda dengan studi yang diteliti oleh Saiti \& Masih (2016), dan (Khan \& Khan, 2018) bahwa indeks saham yang diteliti mengalami hubungan jangka pendek. Menurut Saiti \& Masih (2016) kalkulasi error correction model memiliki informasi bagaimana dalam proses terjadinya hubungan secara jangka panjang akan ada kemungkinan munculnya shock transmission lalu kembali pada titik ekuilibrium jangka panjangnya yang dinotasikan dalam satuan waktu. Namun informasi error correction model tidak dapat ditemukan dalam penelitian ini karena variabel IHSG dan JII tidak mengalami hubungan jangka panjang yang disebabkan karakterisitk indeks saham konvensional dan indeks saham syariah memiliki perbedaan secara fundamental.

Secara teoritis, ketiadaan hubungan jangka pendek melalui pendekatan error correction model memiliki implikasi yaitu tidak sesuainya dengan teori pergerakan bersama karena tidak adanya kointegrasi pada kedua variabel. Namun secara praktis, ketiadaan hubungan jangka pendek memiliki implikasi yaitu investor memiliki kesempatan untuk melakukan diversifikasi aset pada portofolio investasi dan sebagai alat bantu bagi pengambil kebijakan di bidang pasar modal Indonesia.

\section{Hubungan Kausalitas IHSG dengan JII}

Variabel IHSG maupun JII antara satu sama lain tidak memiliki hubungan kausalitas pada variabel IHSG dan JII pada periode 2015-2019 yang diuji secara empiris melalu uji kausalitas Engle-Granger dengan ditunjukkan nilai F-statistik hitung < nilai F-statistik tabel. Temuan ini berbeda dengan studi yang dilakukan oleh Yusuf, et al (2018) bahwa variabel yang diteliti memiliki hubungan kausalitas. 
Studi yang dilakukan oleh Saiti \& Masih (2016) memaparkan bahwa Granger Causality bisa menjelaskan arah pergerakan variabel yang diteliti sehingga investor bisa memonitor kinerja dari aset investasinya lebih akurat pada jenis instrumen apa yang saling mempengaruhi satu sama lain.

Secara teoritis, ketiadaan hubungan kausalitas dengan metode Granger Causality memiliki implikasi bahwa arah pergerakan variabel IHSG dan JII tidak mengalami sebab-akibat yang diakibatkan berbedanya karakteristik pada kedua indeks saham tersebut. Namun secara praktis, ketiadaan kausalitas yang juga merupakan ketiadaan co-movement menjadi benefit bagi investor dalam meletakkan porsi diversifikasi aset berupa pembagian risiko sehingga investor mencapai tujuan investasi yang diinginkan. Lebih jauh, hasil penelitian ini dapat digunakan untuk menganalisis kebijakan pasar modal di Indonesia

\section{KESIMPULAN}

Pergerakan bersama di antara kedua variabel menjadi fokus tujuan dari penelitian ini yang mengungkap apakah indeks saham konvensional yang diproksikan oleh IHSG dan indeks saham syariah yang diproksikan oleh JII memiliki keterkaitan dari sisi co-movement. Pendekatan uji kointegrasi dengan metode Johansen test serta hubungan jangka pendek dengan error correction model dan Uji kausalitas Granger dalam penelitian ini dirangkum dalam beberapa poin yaitu (1) ketiadaan hubungan jangka panjang maupun jangka pendek antara IHSG dengan JII, dan (2) IHSG dan JII tidak memiliki hubungan kausalitas antara satu sama lain. Penggunaan jangka waktu dalam penelitian ini yaitu selama 5 tahun dan menggunakan data sampel bulanan merupakan keterbatasan penelitian yang muncul dalam studi ini. Penggunaan periode penelitian yang lebih panjang dan data yang lebih banyak merupakan saran untuk penelitian selanjutnya supaya bisa lebih menjelaskan hubungan yang dinamis antar variabel IHSG dan JII. Penelitian selanjutnya juga dapat menggunakan instrumen syariah selain JII agar mendapatkan gambaran yang lebih komperehensif

\section{DAFTAR PUSTAKA}

Baur, D. (2003). What is Co-movement?. EUR Working Paper 20759 EN. Retrieved from http://papers.ssrn.com/sol3/papers.cfm?abstract_id=570585

Bursa Efek Indonesia. (2019). PT Bursa Efek Indonesia. Retrieved December 8, 2019, from Produk Syariah website: https://www.idx.co.id/idx-syariah/produk-syariah/

El Amri, H., \& Hamza, T. (2017). Are There Causal Relationships between Islamic versus Conventional Equity Indices? International Evidence. Studies in Business and Economics, 12(1), 40-60. https://doi.org/10.1515/sbe-2017-0004

El Qorchi, M. (2005). Islamic Finance Gears Up. Finance Developmet IMF Magazine. Retrieved from https://www.imf.org/external/pubs/ft/fandd/2005/12/qorchi.htm

Fauzan, M., \& Suhendro, D. (2018). Pasar Modal Syariah Sebagai Sarana Investasi Syariah (Studi Kasus Bursa Efek Indonesia Kantor. Human Falah, 5.

Jebran, K., Zubair, M., Chen, S., \& Zubair Tauni, M. (2017). Islamic And Conventional Equity Index Co-Movement And Volatility Transmission: Evidence From Pakistan. Future Business Journal, 3(2), 98-106. https://doi.org/10.1016/j.fbj.2017.05.001

Ojk.go.id. (2019). Daftar Efek Syariah. Retrieved from https://ojk.go.id/id/kanal/syariah/data-danstatistik/daftar-efek-syariah/Default.aspx

Khan, S. N., \& Khan, W. A. (2018). Co-Integration Between Islamic And Conventional Stock Market Index: An Investigation Of Diversification (A Case Of Asian Pacific Region). Pakistan 
Ahmad Hilmy \& Yuyun Isbanah. Cointegration Indeks Harga Saham Gabungan dan Jakarta Islamic Index Periode 2015-2019

Business Review, 20(2), 341.

Kompas. (2019). Investor Saham Syariah Naik 2.323 Persen dalam 5 Tahun Terakhir. Retrieved December 8, 2019, from Kompas website: https://money.kompas.com/read/2019/11/21/210000026/investor-saham-syariah-naik-2.323persen-dalam-5-tahun-terakhir

Majdoub, J., Mansour, W., \& Jouini, J. (2016). Market integration between conventional and Islamic stock prices. North American Journal of Economics and Finance, 37, 436-457. https://doi.org/10.1016/j.najef.2016.03.004.

Malhotra, N., \& Birks, D. (2007). Marketing Research: An Applied Approach. England: Pearson Education Limited

Mardatillah, T. A., \& Satibi, I. (2018). Analisis Interdependensi Pasar Modal Syariah Dan Konvensional Di Indonesia (Studi Pada Jakarta Islamic Index Dan LQ45). Thesis, Jakarta: UIN Sunan Kalijaga

Muhajir, M. H. (2008). Analisis Kointegrasi: Keterkaitan Jakarta Islamic Indeks Dengan IHSG Dan SBI Di Bursa Efek Jakarta(Periode April 2005- Juli 2007) (Universitas Diponegoro).

Rosadi, D. (2012). Ekonometrika \& Analisa Runtun Waktu Terapan dengan Eviews (1st ed.). Yogyakarta: Andi.

Safwan, M. A. M. N. (2016). Performance Analysis Between Shariah- Compliant And Conventional Indices In US And Malaysia And Their Long-Term Relationships. Dissertation, Glasgow: University Of Glasgow. 0-52. https://doi.org/10.13140/RG.2.1.3104.9848

Saiti, B. (2014). Integration between the Conventional and Islamic Stock Indices with the US: Evidence from Cointegration Analysis. Australian Journal of Basic and Applied Sciences, (June), 18-30.

Saiti, B., \& Masih, M. (2016). The Co-Movement Of Selective Conventional And Islamic Stock Indices: Is There Any Impact On Shariah Compliant Equity Investment In China? International Journal of Economics and Financial Issues, 6(4), 1895-1905.

Tandelilin, E. (2010). Portofolio Dan Investasi: Teori Dan Aplikasi. Yogyakarta: Kanisius

Utami, A. T. (2018). Stock Market Co-Integration Evidence from Indonesia, Malaysia, South Korea, Hong Kong, and The US Stock Market. Jurnal Manajemen Dan Bisnis: Performa, 15(2), 7586.

Wibowo, B. (2017). Pergerakan Bersama Indeks Pasar Saham Syariah Dan Variabel Makro Ekonomi: $\begin{array}{lllll}\text { Pendekatan Regime-Switching } & \text { Regression. } & \text { Iqtishadia, }\end{array}$ https://doi.org/10.21043/iqtishadia.v10i2.2237

Winarno, W. W. (2017). Analisis Ekonometrika dan Statistika dengan Eviews (5th ed.). Yogyakarta: UPP STIM YKPN.

Yaqin, M. A. (2010). Kontribusi Pasar Modal Syariah Terhadap Pembangunan Hukum Pasar Modal Nasional. Jurnal Law Reform, Volume 5(2), 97-105.

Yusuf, A. A., Wartoyo, \& Rahmiyati. (2018). Analisis Kausalitas Antara Harga Saham Konvensional Dengan Harga Saham Syariah Di Indonesia (Pendekatan Granger Causality). El-Jizya: Jurnal Ekonomi Islam, 6(2), 156-180. https://doi.org/10.24090/ej.v6i2.2035 